\title{
Perbedaan Morfologi dan Fragmentasi DNA Sperma sebelum dan sesudah Kriopreservasi dengan Metode Slow Cooling di Klinik Aster RSUP Dr. Hasan Sadikin Bandung
}

\author{
Faizal Arif, ${ }^{1}$ Tono Djuwantono, ${ }^{2}$ Dian Tjahyadi, ${ }^{2}$ Yusuf Sulaeman Effendi, ${ }^{2}$ Anita Deborah \\ Anwar, ${ }^{2}$ Amillia Siddiq ${ }^{2}$ \\ ${ }^{1}$ Rumah Sakit Ibu dan Anak Asyiyah Samarinda Kalimantan Timur \\ ${ }^{2}$ Departemen Obstetri dan Ginekologi Fakultas Kedokteran Universitas Padjadjaran \\ Rumah Sakit Dr. Hasan Sadikin Bandung \\ Korespondensi: Faizal Arif, Email: faizalarif1984@gmail.com
}

\begin{abstract}
Abstrak
Tujuan: Penelitian ini bertujuan untuk mengetahui perbedaan parameter fragmentasi DNA, morfologi sperma pasca proses pembekuan dengan metode slow cooling.

Metode: Penelitian ini merupakan penelitian obervasional analitik dengan pendekatan pre-post design. Subjek penelitian adalah sperma dengan hasil analisis yang normal sesuai dengan standar WHO $(n=25)$. Penelitian dilakukan di Klinik Aster RSUP Dr. Hasan Sadikin Bandung pada bulan Juli hingga Agustus 2017.

Hasil: Setelah proses kriopreservasi, terdapat peningkatan fragmentasi DNA tiga kali lipat (nilai $p<0,05)$ dan terdapat penurunan jumlah morfologi normal sebesar $50 \%$ (nilai $\mathrm{p}<0,05$ ).

Kesimpulan: Terdapat penurunan kualitas sperma pasca proses kriopreservasi dengan metode slow cooling.
\end{abstract}

Kata kunci: Fragmentasi DNA, morfologi, slow cooling, spermatozoa

\section{Difference of DNA Fragmentation, Morphology Sperm before and after Cryopreservation with Slow Cooling Method in Aster Fertility Clinic Dr. Hasan Sadikin General Hospital Bandung}

\footnotetext{
Abstract

Objective: Of this study was to compare sperm quality parameters including DNA fragmentation and morphology after cryopreservation with slow-cooling method.

Method: This was an analytical observational study with pre and post design. Subjects were men whose sperm analysis met the WHO criteria of being normal $(n=25)$. The study was conducted at the Aster Clinic of Dr. Hasan Sadikin General Hospital Bandung from July to August 2017.

Results: After cryopreservation, there was a three fold increase of DNA fragmentation (with $p$ value $<0.05$ ) and a decrease in morphology 50\% (with p value $<0.05$ ).

Conclusion: There is a decrease in sperm quality after cryopreservation with slow-cooling method.
}

Key words: DNA fragmentation, morphology, slow cooling, spermatozoa 


\section{Pendahuluan}

Infertilitas adalah ketika pasangan gagal mencapai kehamilan setelah setidaknya 12 bulan melakukan hubungan seksual reguler tanpa menggunakan kontrasepsi. Jenis infertilitas ini juga disebut infertilitas primer. Gangguan kesuburan dapat menyebabkan dampak yang besar bagi pasangan, tidak hanya mengenai masalah medis tetapi juga masalah ekonomi dan psikologis. ${ }^{1} \mathrm{Di}$ Indonesia, terdapat $40 \%$ pasangan usia subur dan $10 \%$ di antara pasangan tersebut mengalami infertilitas. Penyebab infertilitas pada pasangan suami istri dapat diklasifikasikan menjadi tiga kelompok, dengan proporsi sebagai berikut: faktor wanita $45 \%$, faktor pria $40 \%$ dan faktor idiopatik $15 \%$. Salah satu metode untuk mengevaluasi etiologi infertilitas yang terkait dengan pria adalah dengan menilai kualitas semen, yaitu analisis sperma. Beberapa parameter analisis sperma yang dapat dievaluasi meliputi morfologi, konsentrasi, kromatin, dan fragmentasi DNA sperma. $^{2}$

Salah satu cara untuk mengatasi masalah ketidaksuburan pada pria adalah dengan melestarikan spermatozoa. Metode yang paling umum digunakan untuk melestarikan spermatozoa adalah dengan kriopreservasi. Kriopreservasi adalah teknik untuk melestarikan bahan genetik dalam kondisi beku di bawah suhu rendah melalui pengurangan aktivitas metabolik tanpa mempengaruhi organel intraselular, atau fisiologis, biologi, dan morfologi sel. Teknik kriopreservasi dapat dikelompokkan menjadi metode pendinginan lambat (slow cooling) dan metode pendinginan cepat (vitrification). Teknik kriopreservasi yang paling sering dilakukan sampai saat ini adalah metode pendinginan lambat. Metode ini telah sering diterapkan untuk melestarikan berbagai sel, jaringan, serta organ tubuh manusia. ${ }^{3,4}$

Proses kriopreservasi spermatozoa menggunakan metode pendinginan lambat (slow cooling) pada berbagai penelitian sebelumnya dilaporkan memiliki hasil dan hasil yang bervariasi. Sinan dkk. melaporkan bahwa terdapat penurunan kualitas morfologi, sementara saat menilai fragmentasi DNA, dilaporkan bahwa kriopreservasi tidak menyebabkan kerusakan pada sel. Beberapa penelitian lain menunjukkan bahwa ada peningkatan fragmentasi DNA setelah kriopreservasi. Pattama dkk melaporkan bahwa motilitas dan fragmentasi DNA meningkat setelah kriopreservasi dengan metode pendinginan lambat. ${ }^{5-10}$ Perbedaan ini mungkin karena metode kriopreservasi yang berbeda, yaitu antara metode pendinginan lambat dan vitrifikasi. Diharapkan, penelitian ini dapat mengevaluasi perbedaan atau jumlah fragmentasi DNA setelah kriopreservasi sperma dengan metode pendinginan lambat. Akhirnya, penelitian ini berharap bisa membantu keluarga yang mengalami kemandulan dan ingin mendapatkan keturunan.

\section{Metode}

Penelitian ini merupakan penelitian analitik observasional dengan pendekatan desain studi pra-pasca dari bulan Juli-Agustus 2017 di Instalasi reproduksi berbantu umum Dr. Hasan Sadikin Bandung. Pengumpulan sampel dilakukan dengan menggunakan metode sampling berturut-turut dan subjek dialokasikan secara acak ke dalam salah satu dari kedua kelompok. Spesimen penelitian adalah spesimen sperma dengan hasil analisis normal berdasarkan standar WHO yang dikumpulkan dari pria usia subur yang datang ke klinik aster RSUP Dr. Hasan Sadikin Bandung. Kriteria inklusi dari penelitian ini meliputi: 1). bersedia berpartisipasi sebagai subjek penelitian, 2). pria usia subur 20-35 tahun, dan 3). memiliki hasil analisis sperma yang normal berdasarkan kriteria WHO. Sedangkan kriteria eksklusi dari penelitian ini meliputi: 1). Ada kelainan 
yang ditemukan pada hasil analisis sperma, dan 2) pasien memiliki alasan tertentu untuk tidak berpartisipasi sebagai subjek penelitian. Penelitian ini dilakukan setelah menerima kesepakatan dan rekomendasi dari Komite Etika Penelitian Kesehatan, Fakultas Kedokteran Universitas Padjadjaran, Rumah Sakit Umum Dr. Hasan Sadikin Bandung.

Pasien yang memenuhi kriteria inklusi dan bersedia mengikuti penelitian ini setelah diberi penjelasan dan telah menandatangani informed consent tertulis akan diminta mengikuti prosedur berikut, yaitu kumpulan sampel sperma. Sampel sperma yang telah dianalisis dan ternyata normal akan menjalani pencucian dengan menggunakan centrifuge selama 5-10 menit. Setelah prosedur pencucian, spesimen akan dibagi menjadi 2, yaitu: 1). spesimen untuk penilaian parameter morfologi, dan 2). spesimen untuk penilaian fragmentasi DNA menggunakan metode Sperm Chromatin Disperse (SCD). Kedua spesimen spermatozoa tersebut akan menjalani kriopreservasi dengan metode pendinginan lambat. Spesimen spermatozoa beku akan disimpan dalam tabung khusus selama sebulan dan kemudian akan dicairkan.

Variabel spesimen sperma, yang akan diteliti dalam penelitian ini, meliputi sperma (diamati dari jumlah dan motilitas sperma yang layak), morfologi sperma, dan fragmentasi DNA sperma. Data yang dihitung kemudian diolah dengan analisis deskriptif dan analitik. Analisis deskriptif terhadap data akan disajikan sebagai mean, standar deviasi, median, dan range. Uji statistik yang digunakan untuk membandingkan sperma sebelum dan sesudah prosedur dipasangkan uji $\mathrm{T}$ atau uji Wilcoxon jika datanya tidak terdistribusi normal. Hasil dianggap signifikan jika $\mathrm{p}<0,05$.

\section{Hasil}

Penelitian ini dilakukan selama satu bulan dari bulan Juli sampai Agustus 2017. Dua puluh lima spesimen spermatozoa normal berdasarkan standar WHO diproses dan ditambahkan dengan larutan krioprotektan. Spesimen campuran kemudian diberi cryopreserved dengan metode pendinginan yang lambat.

Tabel 1 menyajikan perbandingan fragmentasi DNA di dalam spesimen sebelum dan sesudah kriopreservasi yang dihitung dengan menggunakan uji statistik Wilcoxon. Fragmentasi DNA ditemukan tiga kali lebih tinggi setelah kriopreservasi $(\mathrm{p}<0,05)$.

Tabel 2 menyajikan perbandingan morfologi sperma sebelum dan sesudah kriopreservasi dihitung dengan menggunakan uji paired-T. Kami menemukan bahwa rata-rata skor morfologi normal sebelum kriopreservasi lebih tinggi dibandingkan dengan kriopreservasi. Skor rata-rata sebelum kriopreservasi adalah 2,2(1,6), sedangkan nilai rata-rata setelah kriopreservasi adalah 1,4(1,1). Dengan demikian, dapat disimpulkan bahwa ada penurunan jumlah sperma yang signifikan secara statistik sebesar 50\% dengan morfologi normal setelah kriopreservasi $(\mathrm{p}=0,05)$.

\section{Tabel 1 Perbandingan Fragmentasi DNA sebelum dan sesudah Kriopreservasi dengan Metode Pendinginan Lambat}

\begin{tabular}{lccc}
\hline \multirow{2}{*}{$\begin{array}{l}\text { Fragmentasi } \\
\text { DNA }\end{array}$} & \multicolumn{2}{c}{ Pengukuran } & \multirow{2}{*}{ nilai-p * } \\
\cline { 2 - 3 } $\begin{array}{lcc}\text { Rerata } \\
\text { (Std Deviasi) }\end{array}$ & $0,1(0,1)$ & $0.2(0,3)$ & $<\mathbf{0 , 0 0 1}$ \\
Median & 0,018 & 0,147 & \\
& $0,00-$ & $0,009-$ & \\
Kisaran & 0,243 & 0,990 & \\
\end{tabular}

Catatan: * dihitung berdasarkan uji Wilcoxon, * pre: pre washing, post: post thawing 
Tabel 2 Perbandingan Morfologi sebelum dan sesudah Kriopreservasi dengan Metode Pendinginan Lambat

\begin{tabular}{lccc}
\hline \multirow{2}{*}{ Morfologi } & \multicolumn{2}{c}{ Pengukuran } & nilai-p* \\
\cline { 2 - 3 } & Pre & Post & \\
Rerata \pm Std Deviasi & $2,2(1,6)$ & $1,4(1,1)$ & 0,005 \\
Median & 2 & 1 & \\
Kisaran & $0,00-5.00$ & $0,00-4,00$ & \\
\hline
\end{tabular}

Catatan: nilai-p dihitung berdasarkan uji $\mathrm{T}$ berpasangan.

\section{Pembahasan}

Kriopreservasi adalah teknik untuk melestarikan bahan genetik dalam kondisi beku di bawah suhu rendah atau melalui pengurangan aktivitas metabolik tanpa mempengaruhi organel di dalam sel, fungsi fisiologis dan biologis serta morfologi. Kriopreservasi sperma merupakan bagian penting dari banyak laboratorium yang menyediakan Assisted Reproductive Technology (ART), terutama untuk In Vitro Fertilization (IVF) dan Intracytoplasmic Sperm Injection (ICSI). ${ }^{11}$

Metode kriopreservasi sperma menginduksi beberapa perubahan dan kerusakan parameter sperma melalui berbagai metode, yang pada akhirnya dapat menyebabkan penurunan viabilitas sperma, penurunan motilitas, perubahan pada membran plasma, akrosomia, dan integritas DNA. Stres oksidatif dalam proses pendinginan menghasilkan radikal bebas, yang menyebabkan proses lipoperoksidase, yang akan menyebabkan hilangnya motilitas ireversibel, kebocoran enzim intraselular, kerusakan DNA sperma, dan penurunan kemampuan untuk menembus oosit dan juga fusi sperma-oosit. ${ }^{7}$

Dalam penelitian ini, kami menggunakan metode pendinginan yang lambat. Dalam metode ini, selama proses pendinginan, saat suhu menjadi sangat dingin, kristal es akan terbentuk dari air ekstraselular yang mengelilingi spermatozoa. Kristal es ini akan meningkatkan konsentrasi natrium, glukosa, dan protein. Pada kondisi ini, tekanan osmotik di luar sel akan meningkat secara bertahap, menyebabkan cairan intraselular bocor di luar, terutama dari kepala spermatozoa dan menyebabkan dehidrasi di dalam sel. Metode pendinginan yang lambat juga menyebabkan perubahan transisi fase lipid, peningkatan lipid peroxidase, dan produksi spesies oksigen reaktif (ROS). Semua proses ini dapat menurunkan parameter spermatozoa. ${ }^{5,8,12,13}$ Secara keseluruhan, hasil dalam penelitian ini menunjukkan bahwa prosedur pendinginan dan pencairan dapat menyebabkan perubahan morfologi sperma. Sementara itu, pada analisis integritas DNA, kami menemukan peningkatan fragmentasi DNA pasca pendinginan dan prosedur pencairan.

Terdapat peningkatan fragmentasi DNA rata-rata pasca kriopreservasi; yaitu dari $0,5(0,6)$ sampai $0,2(0,2)$. Kenaikan ini mencerminkan penurunan kualitas spermatozoa. Proses dehidrasi yang terjadi selama kriopreservasi menyebabkan kristalisasi intraselular, yang akan mempengaruhi fungsi membran seluler. Kerusakan akibat kristalisasi akan mengganggu kondensasi kromatin, protamin dan kompleks DNA, mengakibatkan kerusakan DNA sperma. Proses pendinginan dan pencairan menyebabkan kerusakan kromatinyang signifikan. Kelainan Chromatin 
mempengaruhi kualitas sperma dan status kesuburan pria. Sumber utama fragmentasi DNA adalah: cacat karena rekombinasi bahan genetik selama spermatogenesis, pematangan abnormal (protopati abnormal), apoptosis sel punca testis, dan stres oksidatif. Dari semua faktor tersebut, penyebab utama kerusakan DNA pada spermatozoa adalah stres oksidatif, yang dimediasi oleh beberapa variasi spesies oksigen reaktif (ROS), termasuk radikal bebas, seperti anion superoksida $(\mathrm{O} 2-\bullet)$, nitrit oxide $(\mathrm{NO}+)$, atau radikal hidroksil $(\mathrm{OH}+)$ serta oksidan kuat seperti hidrogen peroksida (H2O2) atau perokinitrit (ONOO-). Spermatozoa sangat rentan terhadap stres oksidatif karena kapasitas defensif antioksidannya yang terbatas, karena hilangnya sebagian besar sitoplasma selama spermatogenesis dan penurunan jumlah antioksidan sitoplasma seperti katalase atau superoksida dismutase. Stres oksidatif terjadi pada spermatozoa karena produksi ROS mitokondria yang berlebihan, sebagai akibat dari jalur apoptosis intrinsik. Kondisi yang dapat menyebabkan hilangnya perlindungan antioksidan meliputi merokok, kebiasaan makan/pola makan yang buruk, atau inkubasi kultur yang berkepanjangan tanpa suplemen antioksidan. Kondisi ini juga menyulitkan stres oksidatif dan kerusakan DNA oksidatif pada populasi spermatozoa. Namun, sperma yang DNAnya sudah rusak masih bisa membuahi sel telur dan akhirnya menyebabkan mutasi pada embrio, yang sayangnya jarang didiagnosis sampai embrio mencapai stadium blastosis atau telah menjadi janin.

Perkembangan mengenai evaluasi fragmentasi DNA memerlukan penelitian lebih lanjut dengan pendekatan yang berbeda untuk mengevaluasi kerusakan DNA. Dalam kasus ini, hasil yang berlawanan dilaporkan dalam sumber literatur, dengan beberapa menunjukkan kerusakan DNA setelah kriopreservasi. ${ }^{14-17}$ Penelitian oleh Simonenko menemukan bahwa fragmentasi meningkat sebesar 7,7(7,9\%). Kriopreservasi juga dilaporkan mengubah kondensasi kromatin spermatozoa dalam penelitian oleh Boitrelle, yaitu sebesar $17 \%$ untuk pasien dengan sperma normal dan 24,5\% untuk pasien dengan teratozoospermia. Di sisi lain, beberapa penelitian menemukan bahwa tidak ada kerusakan pada spermatozoa setelah kriopreservasi. Pattama dkk menyatakan bahwa motilitas dan fragmentasi DNA memiliki hasil yang lebih baik setelah kriopreservasi dengan metode pendinginan lambat. Penelitian lain oleh Vutyavanich dkk di Thailand menemukan bahwa integritas DNA sperma tidak dipengaruhi oleh prosedur pendinginan dan pencairan, yang tercermin dari perubahan DNA sperma dan ekor yang tidak signifikan selama penilaian komet. Dari data yang ada, dapat disimpulkan bahwa ada variabilitas fragmentasi DNA sperma yang signifikan setelah proses kriopreservasi, yang merupakan kejadian yang cukup tinggi pada kasus individu. ${ }^{5,7,9,10,18-21}$

Persentase morfologi normal sperma sebelum dan sesudah kriopreservasi menurun dari 2,2(1,6) menjadi 1,4(1,1). Ada laporan hubungan antara morfologi dan fragmentasi DNA. Gambaran morfologi sperma adalah representasi status genom sperma. Beberapa penelitian melaporkan bahwa kerusakan fisik langsung pada struktur sperma berhubungan dengan pembentukan es dan tekanan osmotik tinggi selama pembekuan. Pembekuan meningkatkan konsentrasi kandungan terlarut, seperti sodium, glukosa, dan protein, sebagai respon terhadap peningkatan tekanan osmotik yang meningkat ini dan fakta bahwa kandungan air dalam spermatozoa membentuk kristal es lebih lambat daripada air dari medium sekitarnya karena tekanan osmotik di luar sel. lebih tinggi dari pada sel. Akibatnya, spermatozoa terkena dehidrasi dan kerusakan fisik; misalnya ekor yang digulung. Selama proses pendinginan yang lambat, dehidrasi spermatozoa dapat berlanjut ke titik ekuilibrium osmotik 
antara ruang intraselular dan ekstraselular dengan dehidrasi seluler maksimum, yang tidak menguntungkan. Namun, peningkatan kecepatan proses pembekuan tidak akan menghalangi pembentukan es intraselular akibat dehidrasi yang lambat. Selain itu, proses pembekuan terlalu cepat dapat menyebabkan pembentukan es intraselular dan pecahnya membran plasma sperma, serta kerusakan organ intraselular. Selain itu, ada juga peningkatan risiko kerusakan sel mekanis akibat kompresi es ekstraselular, yang menyebabkan deformasi sel dan kerusakan membran lebih lanjut. Laju pendinginan sperma harus optimal untuk menurunkan kadar zat yang terlarut dan dehidrasi intraselular, untuk mengurangi penyusutan sel sperma. Penelitian oleh Sinan dkk juga melaporkan hasil yang serupa; Persentase morfologi normal menurun setelah kriopreservasi. Studi oleh Vutyavanich dkk di Thailand juga menemukan bahwa metode pendinginan yang lambat menghasilkan

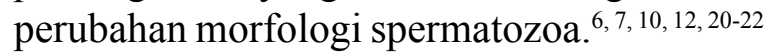

Penelitian selanjutnya diperlukan untuk mengevaluasi hubungan antara hasil kriopreservasi sperma dan hasil reproduksi pasca melahirkan (IVF). Temuan ini mungkin bermanfaat karena evaluasi terus menerus terhadap sperma cryopreserved dengan menggunakan prosedur reproduksi dibantu. Simpulan, fragmentasi DNA spermatozoa meningkat setelah kriopreservasi dengan metode pendinginan yang lambat. Morfologi sperma normal juga menurun setelah kriopreservasi dengan metode pendinginan lambat.

\section{Daftar Pustaka}

1. Mazur P. Principles of cryobiology: life in the frozen state.Edisi.: CRC Press; 2004.

2. Lestari S, Sari T. Fragmentasi DNA Spermatozoa: Penyebab, Deteksi, dan Implikasinya pada Infertilitas Laki-Laki. eJournal Kedokteran Indonesia. 2015.
3. Storey K, Storey J. Frozen and alive. Scientific American. 1990;263(6):9-27.

4. Rocha V, Cornish J, Sievers E, Filipovich A, Locatelli F, C Peters ea. Comparison of outcomes of unrelated bone marrow and umbilical cord blood transplants in children with acute leukemia. Blood. 2001;97(10):2962-71.

5. Santo MD, Tarozzi N, Nadalini M, Borini A. Human sperm cryopreservation: update on techniques, effect on DNA integrity, and implications for ART. Adv Urol. 2012.

6. Ozkavukcu S, Erdemli E, Isik A, Oztuna D, Karahuseyinoglu S. Effects of cryopreservation on sperm parameters and ultrastructural morphology of human spermatozoa. J Assist Reprod Genet. 2008;25(8):403-11.

7. Rahiminia T, Hosseini A, Anvari M, Ghasemi-Esmailabad S, Talebi A. Modern human sperm freezing: Effect on DNA, chromatin and acrosome integrity. Taiwan J Obstet Gynecol. 2017;56(4):472-6.

8. Mohamed M. Slow cryopreservation is not superior to vitrification in human spermatozoa; an experimental controlled study. Iran J Reprod Med. 2015;13(10):633.

9. Boitrelle F, Albert M, Theillac C, Ferfouri F, Bergere M, F Vialard ea. Cryopreservation of human spermatozoa decreases the number of motile normal spermatozoa, induces nuclear vacuolization and chromatin decondensation. Journal Androl. 2012;33(6):1371-8.

10. Tongdee P, Sukprasert M, Satirapod C, Wongkularb A, Choktanasiri W. Comparison of Cryopreserved Human Sperm between Ultra Rapid Freezing and Slow Programmable Freezing: Effect on Motility, Morphology and DNA Integrity. J Med Assoc Thai. 2015;98:S33-42.

11. Virro M, Larson-Cook K, Evenson D. Sperm chromatin structure assay 
$(\mathrm{SCSA} \circledast)$ parameters are related to fertilization, blastocyst development, and ongoing pregnancy in in vitro fertilization and intracytoplasmic sperm injection cycles. Fertil Steril. 2004;81(5):1289-95.

12. Lemma A. Effect of cryopreservation on sperm quality and fertility. Artificial insemination in farm animals. InTech. 2011.

13. Agarwal A, Tvrda E. Chapter 5 Slow Freezing of Human Sperm. Cryopreservation of Mammalian Gametes and Embryos. Methods and Protocols. 2017:67-78.

14. Orief Y, Schultze-Mosgau A, Dafopoulos K, 2005;10(3):171. SA-H. Vitrification: will it replace the conventional gamete cryopreservation techniques. Middle East Fertil Soc J. 2005;10(3):171.

15. Thomson L, Fleming S, Barone $\mathrm{K}$, Zieschang J-A, Clark A. The effect of repeated freezing and thawing on human sperm DNA fragmentation. Fertil Steril. 2010;93(4):1147-56.

16. Paula Td, Bertolla R, Spaine D, Cunha M, Schor N, Cedenho A. Effect of cryopreservation on sperm apoptotic deoxyribonucleic acid fragmentation in patients with oligozoospermia. Fertil Steril. 2006;66(3):597-600.

17. Zribi N, Chakroun N, Euch HE, Gargouri J, Bahloul A, Keskes L. Effects of cryopreservation on human sperm deoxyribonucleic acid integrity. Fertil Steril. 2010;93(1):159-66.

18. Gavriliouk D, Aitken R. Damage to sperm DNA mediated by reactive oxygen species: its impact on human reproduction and the health trajectory of offspring. Edisi.: Springer; 2015.

19. Simonenko E, Garmaeva S, Yakovenko S, Grigorieva A, Tverdislov V, A Mironova ea. The influence of the storage temperature and cryopreservation conditions on the extent of human sperm DNA fragmentation. Biophysics. 2016;61(2):267-70.

20. Vutyavanich T, Lattiwongsakorn W, Piromlertamorn W, Samchimchom S. Repeated vitrification/warming of human sperm gives better results than repeated slow programmable freezing. Asian $\mathrm{J}$ Androl. 2012;14(6):850.

21. Vutyavanich T, Piromlertamorn W, Nunta S. Rapid freezing versus slow programmable freezing of human spermatozoa. Fertil Steril. 2010;93(6):1921-8.

22. Moskovtsev S, Lulat A-M, Librach C. Cryopreservation of human spermatozoa by vitrification vs. slow freezing: Canadian experience. Current Frontiers in Cryobiology. 2012. 